\title{
The Financial Conditions and Prospects of the Municipality of Bitola, Republic of Macedonia
}

\author{
Nikolche Jankulovski ${ }^{1}$, Katerina Bojkovska ${ }^{1}$ \& Goran Mihajlovski ${ }^{1}$ \\ ${ }^{1}$ University St. Kliment Ohridski, Bitola, Republic of Macedonia \\ Correspondence: Nikolche Jankulovski, University St. Kliment Ohridski, Bitola, Macedonia, ul.140 br.8 Bitola, \\ Macedonia. Tel: 00389-75-401005. E-mail: nikolcejankulovski@yahoo.com
}

Received: August 3, 2014

Accepted: August 14, 2014

Online Published: October 25, 2014

doi:10.5539/ijef.v6n11p197

URL: http://dx.doi.org/10.5539/ijef.v6n11p197

\begin{abstract}
Funding is the most important instrument in the implementation of local economic development. Municipalities in the Republic of Macedonia are constantly facing the shortage of funds for implementation of their ongoing activities, and for undertaking new project assignments. In this regard, despite funding from their own resources, the municipalities have funds received by transfer from the central government, donations and funds raised through borrowing made by the local businesses. The financial assets that can be obtained from the EU (European Union) funds, public-private partnerships and the issuance of municipal bonds are incipient. In this regard, the local municipal authorities should combine multiple opportunities to fund projects that will provide better living standard of the population and rapid economic development of the municipality. The basic working hypotheses for this paper include the following:

- Municipalities, as independent territorial units, have the opportunity to create their own policies to implement projects that will bring positive changes in the daily life of the population;

- Possible implementation and creation of sustainable local economic development and

- Local authorities in the Republic of Macedonia can successfully combine and consistently manage the financial instruments that are available and which are the reason for falling behind of the overall development of the municipality. It can be an encouraging incentive for research on the actual situations and prospects for successful combining of the financial instruments.

For obtaining funds from the international financial organizations such as the World Bank and the International Monetary Fund, the credit rating that the municipalities enjoy is very important as well as their fiscal capacity that could withstand these borrowings. These two indicators, the fiscal capacity and the credit rating of the municipality, specifically of the Municipality of Bitola are studied in this paper. By borrowing through credit lines there is a risk for refund. Therefore, categories and indicators of the credit risk of municipalities are also covered.
\end{abstract}

Keywords: financial conditions, income, budget, risk, Bitola

\section{Application of the Model for Assessment of the Credit Condition of the Municipality of Bitola}

To make good assessment of the credit condition of the Local Self Government Unit (LSU) it is necessary to perform financial analysis over revenue and expenditure budget for the past several years, and to analyze the other factors that affect the solvency of the LSUs.

\subsection{Financial Analysis on the Basis of the Materialized Budgets in the Municipality of Bitola}

This analysis is made on the basis of data on the Budget of the Municipality of Bitola for the period 2009-2012 year. The fiscal indicators are calculated for revenue, expenditure, capital receipts and capital expenditures, as well as the indicators of population.

According to the analyiss (Table 1), we conclude substantial level of flexibility in terms of revenue. The Municipality of Bitola during its operations in the past three years, notes relatively low level of dependence on central transfers illustrated by the continued rise of its own revenues in total revenues, from $68.7 \%$ in 2009 . of $70.7 \%$ in $2010,73.5 \%$ in 2011 and $75.5 \%$ in 2012 . At the expense of that, as expected, the impact of transfers from the central government is reduced from $31.3 \%$ in 2009 to $29.3 \%$ in $2010,25.7 \%$ in 2011 and $25.5 \%$ in 2012 
as a share in the total revenues of the core budget of the municipality. The revenues from the newly introduced so-called shared taxes VAT (Value Added Tax) and PDD (Personal Income Tax) in the first year after the introduction of fiscal decentralization increased the share of the total income, while in 2012 there was a reduction of $16 \%$ due to the increased level of generating their own income.

Table 1. Indicators for income, Municipality of Bitola, for the period 2009-2012, in \%

\begin{tabular}{lrrrr}
\hline & 2009 & 2010 & 2011 & 2012 \\
\hline Tax revenues / Personal revenues & 86.9 & 90.6 & 90.1 & 91.1 \\
Tax revenues / Total revenues & 59.7 & 64.1 & 66.2 & 67.2 \\
Tax revenues / Transfers from central government & 190.8 & 219.1 & 257.5 & 280.4 \\
Personal revenues / Total revenues & 68.7 & 70.7 & 73.5 & 75.5 \\
Personal revenues / Transfers from central government & 219.6 & 241.8 & 285.9 & 320.0 \\
Revenues from fees and commissions / Personal revenues & 40.3 & 40.8 & 44.6 & 45.5 \\
Revenues from fees and commissions / Total revenues & 27.7 & 28.9 & 32.8 & 34.3 \\
Revenue from VAT and PDD / Total revenues & 13.8 & 25 & 17 & 22.2 \\
Transfers from the central government / Total revenues & 31.3 & 29.3 & 25.7 & 16.0 \\
Current operating income / Total revenues & 26.2 & 27.7 & 41 & 42.1 \\
\hline
\end{tabular}

Source. Own calculations based on data for the execution of the budgets for 2009, 2010, 2011 and 2012 obtained from Department of Finance and Budget, Municipality of Bitola.

The share of tax revenues in total revenues record a slight increase or $67.2 \%$ versus $59.7 \%$, in 2008 compared with 2009. This increase indicates that the municipality is able to generate significantly increased level of tax revenues as a result of the increased tax base, and the increased fiscal effort due to the transfer of the competences from central to local level.

The level of implementation of the current operating income, as well as of the current-operating expenditure concludes that the current operating expenditures in 2011 accounted for $52.6 \%$ of the total current-operating incomes, while in 2012 we conclud declining and it is $51.2 \%$. This favorable trend points to the conclusion that the rest of the funds can be used for borrowing of the Municipality of Bitola (Table 2).

Table 2. Indicators of expendure, Municipality of Bitola, for the period 2009-2012, in \%

\begin{tabular}{lcccc}
\hline & 2009 & 2010 & 2011 & 2012 \\
\hline Current operating level/Current operating expenditures & 49.8 & 45.2 & 90.3 & 92.8 \\
Current operating expenditures /Current operating income & 66.7 & 68.9 & 52.6 & 51.2 \\
Capital expenditure /Total budget expenditures & 43.1 & 36.6 & 38 & 40.2 \\
Capital expenditure/Current operating expenditures & 75.8 & 57.7 & 61.4 & 63.3 \\
\hline
\end{tabular}

Source: Own calculations based on data for the execution of the budgets for 2009, 2010, 2011 and 2012 obtained from Department of Finance and Budget, Municipality of Bitola.

In the first two analyzed budget years we have noted a stable level of the current operating performance in relation to the current operating expenditures in the past two years, Index 49.8 (2095) or 45.2 (2010), indicating a very solid credit potential of the municipality for taking credit commitments, and in 2012 this potential to become even stronger as perceived by the index of 92.8 .

Also, a relatively stable is the level of the investment activity in the municipality, although the share of the capital expenditures in the total expenditures in 2010 was $36.6 \%$ and decreased by 6.5 percentage points compared to 2009, but the absolute amount of the capital investment did not decrease in 2011 and 2012 (Table 3). This situation is due to the increased total budget expenditures of the municipality in 2010 compared to 2009. In 2011, again we record a slight increase in relative and absolute terms, i.e. the share of the capital expenditures in the total expenditures increased to $41.2 \%$. 
Table 3. Capital revenue/capital expenditure, municipality of Bitola, for the period of 2009-2012, in \%

\begin{tabular}{lrrrl}
\hline & 2009 & 2010 & 2011 & 2012 \\
\hline Capital revenues/Total revenues & - & - & - & - \\
Transfers for capital purposes/Total revenues & 21.1 & 10.9 & 12.8 & 14.4 \\
Capital expenditures/Total expenditures & 43.1 & 36.6 & 38 & 41.2 \\
\hline
\end{tabular}

Source: Own calculations based on data for the execution of the budgets for 2009, 2010, 2011 and 2012 obtained from Department of Finance and Budget, Municipality of Bitola.

A similar situation is noticed in relation to the capital expenditures compared to the degree of realization of the current-operating expenses. That is, from a level of implementation of $75.8 \%$ in relation to the implemented expenses in 2009, this percent decreased to $57.5 \%$ in 2010 while in 2011 and 2012 we noticed an increase of the level of $63.3 \%$. This fact speaks about a sufficient degree of achievement of the financial resources of the municipality for capital purposes and demonstrates its commitment to the implementation of capital projects.

On the other hand, with all indicators of population, in comparison to 2012 compared to 2011 i.e., 2011 compared to 2010 we record positive changes, except for the indicator transfers for capital purposes (Table 4). In all other indicators, such as total revenues per capita, there is an increase of 1.897 denars (Note 1) in 2009 and 2.114 in 2010, 3.070 in 2011 and 3.443 in 2012. The remaining most indicative examples, the personal income per capita increased from 1.303 (2009) to 1.495 (2010) i.e. 2.601 denars in 2012, while the capital expenditures maintain the same level of 758 denars in 2009 or 748 denars per capita in 2010 and even in 2011 and 2012 they show a slight increase from the 856 or 923 denars.

Table 4. Indicators for population

\begin{tabular}{lcccc}
\hline & 2009 & 2010 & 2011 & 2012 \\
& MKD & MKD & MKD & MKD \\
\hline Total budged revenue/Population (per capita) & 1.897 & 2.114 & 3.070 & 3.443 \\
Personal revenues/Population & 1.303 & 1.495 & 2.256 & 2.601 \\
Current-operating revenues/Population & 1.497 & 1.883 & 2.653 & 3.058 \\
Capital expenditures/Population & 758 & 748 & 856 & 923 \\
Current-operating expenditures/Population & 999 & 1.297 & 1.394 & 1.567 \\
Transfers from central government/Population & 593 & 618 & 789 & 843 \\
Capital transfers/Population & 340 & 231 & 392 & 432 \\
\hline
\end{tabular}

Source: Own calculations based on data for the execution of the budgets for 2009, 2010, 2011 and 2012 obtained from Department of Finance and Budget, Municipality of Bitola.

Marking the extremely high fiscal effort of the tax administration in collection of the tax revenues, namely they are realized by $102 \%$ compared to the plan, the fact that excess revenues transferred from 2011 to 2012 is very high, 78 million den., deserves to be marked in this analysis. Although this excess occurs mostly as a result that a significant amount of 18 million are transferred from the central government at the end of the year, by which the local government was impossible to initiate tender procedure for spending the funds, as well as that part of the surplus, firstly, the tax revenues are realized quite the end of the budget year, this leads to the conclusion that there was not adequate planning on the revenue side or the expenditure part of the budget is not sufficiently implemented and realized under the planned level.

\subsection{Financial Analysis Based on Budget Projections for the Municipality of Bitola}

Based on data from the nominal budget of the Municipality of Bitola, for the period 2007-2011, the fiscal indicators are shown in Table 5.

From the analyzed data we can see increased tax revenues on GDP (Gross Domestic Product), especially after the implementation of the second phase of the process for fiscal decentralization (from $3.2 \%$ in 2011 to $7.1 \%$ in 2012).

Tax revenues show a relative decline in the total revenue but not due to the decreased implementation of the source incomes but to the increase of the nominal amount of the total revenues. The same trend due to increase of the budget is reflected in the ratio of the recurring revenues on total revenues. The overall structure of their own incomes the share of the income tax move to a level of approximately $75 \%$, suggesting that non-tax 
revenues are still at a level of around $20-25 \%$.

Table 5. Fiscal indicators, municipality of Bitola, 2011-2015

\begin{tabular}{|c|c|c|c|c|c|}
\hline & 2011 & 2012 & 2013 & 2014 & 2015 \\
\hline Total revenues on GDP & $3.2 \%$ & $7.1 \%$ & $6.7 \%$ & $7.1 \%$ & $7.3 \%$ \\
\hline Tax revenues in total revenues & $35.8 \%$ & $20.3 \%$ & $27.5 \%$ & $27.5 \%$ & $27.5 \%$ \\
\hline Current operating revenues in total revenues & $46.6 \%$ & $31.8 \%$ & $25.4 \%$ & $40.1 \%$ & $40.1 \%$ \\
\hline Transfers from the central government in total revenues & $65.2 \%$ & $79.07 \%$ & $73.5 \%$ & $73.5 \%$ & $73.5 \%$ \\
\hline Donations in total revenues & $5.5 \%$ & $4.1 \%$ & $2.6 \%$ & $2.6 \%$ & $2.6 \%$ \\
\hline Capital expenditures in current operating expenditure & $24.9 \%$ & $32.2 \%$ & $21.5 \%$ & $21.5 \%$ & $21.5 \%$ \\
\hline Tax revenues in personal revenues & $76.8 \%$ & $80.2 \%$ & $68.3 \%$ & $68.3 \%$ & $68.3 \%$ \\
\hline
\end{tabular}

Source: Department of Finance and Budget, Municipality of Bitola.

Transfers from the central government for the newly devolved responsibilities, on the one hand and the size of the municipality on the other hand are still high which is an indicator that indicates relatively high dependence of the municipality on transfers that the municipality receives from the central government.

The capital expenditures are relatively stable, but they are still at a low level in terms of total expenditure that indicates that the municipality has outstanding obligations that encumber its ongoing operations and bound the possibility for larger capital investments from its own sources.

Table 6. Legal restrictions on borrowings, municipality of Bitola, 2011-2015

\begin{tabular}{|c|c|c|c|c|c|}
\hline & 2011 & 2012 & 2013 & 2014 & 2015 \\
\hline Total budget & 542.091 .183 & 1.186 .953 .476 & Plan & Plan & Plan \\
\hline Generated current operating revenues & 252.370 .813 & 300.937 .824 & 453.313 .940 & 475.979 .637 & 489.579 .055 \\
\hline \multicolumn{6}{|l|}{ Other revenues } \\
\hline Total & 252.370 .813 & 300.937 .824 & 453.313 .940 & 475.979 .637 & 489.579 .055 \\
\hline $15 \%$ limit for long-term borrowing & $15 \%$ & $15 \%$ & $15 \%$ & $15 \%$ & $15 \%$ \\
\hline Legal limit of total indebtedness & 252.370 .813 & 300.937 .824 & 453.313 .940 & 475.979 .637 & 489.579 .055 \\
\hline Legal limit for annual annuity & 37.855 .622 & 45.140 .674 & 67.997 .091 & 71.396 .946 & 73.436 .858 \\
\hline Current debt service & 0 & 0 & 0 & 0 & 0 \\
\hline Interest rate & 0 & 0 & 0 & 0 & 0 \\
\hline Repayment of principal & 0 & 0 & 0 & 0 & 0 \\
\hline Residual capacity for payment of annuity & 37.855 .622 & 45.140 .674 & 67.997 .091 & 71.396 .946 & 73.436 .858 \\
\hline
\end{tabular}

Source: Department of Finance and Budget, Municipality of Bitola.

From the analysis of the actual current operating incomes, and the legal limit for long term borrowing annual annuity, the municipality of Bitola can regularly repay the annuity which brings an increase of its credit capacity (Table 6).

\subsection{Other Factors that Positively Influence the Solvency of the Municipality}

Despite the positive financial indicators for the movement of incomes and expenses in the municipality of Bitola, a major impact on its solvency have the following things too, the level of indebtedness of the municipality in the past, the great potential for attracting investment, the presence of the diplomatic-consular offices and liaison offices, it is located in the border region with EU country, has good natural conditions etc.

Because of the legal impossibility of municipal borrowing in the past, the Municipality of Bitola has generated no debt, and no debt was encountered in the previous years. At the moment, given that the Municipality of Bitola has no debt obligations, debt indicators can not be considered and because of that they can not affect the assessment of the long-term creditworthiness of the municipality.

The Municipality of Bitola, taking into account the changes in the economic-social living conditions, and the ability for improvement of the local economy, according to the devolved powers in the field of local economic development in the process of decentralization has taken a series of measures and activities that actively support the economic growth. In order to influence the improvement of the conditions for economic development, 
opening of new capacities and increase of the employment, the Municipality of Bitola prepared a construction project for construction of an industrial zone Zabeni, located in the border zone with Greece, and it has already started the initial infrastructure works. This activity is carried out in coordination with the Government of the Republic of Macedonia which financially assists the realization of this project in order to allow faster revival and of the area and coming of the first investors.

The Municipality of Bitola has significant potential to generate additional revenue from their own sources. The municipality could realize additional revenues by increasing the tax base, especially with the new possibilities with the changes in tax laws and the estate tax and the economic capacity, but it can also achieve additional effects based on the establishment of forms of public- private partnerships and lease the facilities owned by the municipality. The ability to increase revenues from their own sources above, a significant contributor to providing higher level of public services, but also an important factor in determining and allocating transfers from the central level.

The following table 7 illustrates the fiscal capacity of the municipality established according to the method for achieving tax revenue. It can be concluded that the fiscal capacity for 2009 is 1.389 denars, in 2010 it increased by $38 \%$ and is set at 1.917 denars per capita, and in 2011 was set at 2.168 denars per capita and 2.440 denars in 2012. But for 2010 it can be concluded that the growth of the fiscal capacity is not accompanied by an appropriate level of fiscal effort and therefore there is a condition of reduced tax revenues per capita in 2010 compared to 2009. Unlike 2010, in 2011 and 2012 we record a reverse trend. The corresponding increase in the realized tax revenue in 2010 was $19.6 \%$, i.e. in absolute numbers 1.355 per capita, in 2011 it reaches 2.032 or 2.251 denars in 2012. The index of realization of the fiscal capacity indicates that the fiscal effort that is invested primarily by the municipal administration in realization of the tax revenues, which was $70.68 \%$ in 2010 , which compared to 2009 means a decrease by 11 percentage points, while in 2011 year a significant increase is recorded, i.e. $93.71 \%$ and $95.2 \%$ in 2015 .

Table 7. Fiscal capacity of municipality of Bitola generated by the method of own revenues

\begin{tabular}{llll}
\hline Year & $\begin{array}{l}\text { Tax revenues / Per capita } \\
\text { MKD }\end{array}$ & $\begin{array}{l}\text { Fiscal capacity/ Per capita } \\
\text { MKD }\end{array}$ & $\begin{array}{l}\text { Index (Tax revenues Per capita } \\
\text { / Fiscal capacity Per capita) }\end{array}$ \\
\hline 2009 & 1.132 & 1.389 & 81,50 \\
2010 & 1.355 & 1.917 & 70,68 \\
2011 & 2.032 & 2.168 & 93,71 \\
2012 & 2.251 & 2.440 & 95,2 \\
\hline
\end{tabular}

Source: Own calculations based on data for the execution of the budgets for 2009, 2010, 2011 and 2012 obtained from Department of Finance and Budget, Municipality of Bitola.

The realization of revenues in the highest degree depends on its own capacities to manage the financial resources available to the municipality, and to a lesser extent on transfers from the central government, which affects the stability of incomes, independent from the central government in making important financial decisions and a certain degree of predictability of the revenues in the future.

\section{Conclusion for the Solvency of the Municipality of Bitola}

The conducted analysis leads to the conclusion that the Municipality of Bitola has expressed flexibility in terms of budget revenues given the fact that it administers and collects local taxes and fees on its own and that personal incomes account for more than $70 \%$ of the total revenue of the municipality.

The stable long-term outlook of the Municipality reflects the current, and the future strengthening of the revenue side of the budget, which in turn is closely linked to the positive economic developments in Bitola.

The realization of the income tax in relation to the planned for 2007, but also the possibility for introduction of a new source of budget revenue, property tax for legal entities, further positively impact the level of current operating income, which will further enhance the solvency of the local government Bitola.

Putting into operation a part of the Industrial Zone Zabeni and attracting new investors will certainly increase the economic potential of the municipality, which will positively reflect and strengthen the municipal budget and of course the credit potential of the municipality.

The expected pressure of the devolved obligations to local level, and their need for adequate funding to ensure quality service delivery, may contribute the solvency to be reduced, but the above-mentioned possibility with the 
new source of tax revenue can offset this pressure.

However, through careful and prudent management of municipal finances, a relatively high level of budget execution, a strong control over the municipal spending, which is currently the strong side of the local government, will allow financing major infrastructure projects, without unduly accumulation of current operating revenues for payment of loans / debts or other contingencies.

The continuation of the current trend of improving the local economy, and the expectation based on predictable sources of tax revenue from the activation of the zone in Zabani as well as on the basis of strengthening the local economy in general in the future, would further increase the solvency of the Municipality Bitola.

\section{References}

Anthony, S., \& Maricial, M. C. (2003). Financial institutions management, A Risk Management Approach (4th ed.). McGraw-Hill Irwin.

Bertelsmann Foundation and World Bank. (2002). Local Economic Development Developing and Implementing Local Economic Development Strategies and Action Plans. Washington.

Bexheti, A. (2007). Financat Publike. UELJ-Arberia Design, Tetove.

Bishev, G., \& Parat, D. (1998). Money and Banking Idioms, Phrases and Articles. English-Macedonian, Danimaks, Skopje.

Boex, J. (2001). An introduction overview of intergovernmental fiscal relation. Fiscal Policy-summer training courses at GSU-Atlanta.

Brigham, E. F. (1983). Finacial management-theory and practice. Chicago.

CEA. (2006). The future of Local Government Finance-Case Stady from Romania, Bulgaria and Macedonia. Skopje.

Jankulovski, N. (2009). Financing local governments units through loans and pre association funds-Conditions and perspectives of Municipality of Bitola. Master Paper work. Institute of Economics-Skopje.

Loughlin, J. et al. (2002). Option for Reforming Local Government Founding to Increase Local Streams of Founding: International Comparisons. Cardiff University, Cardiff.

Martinez, V. J., \& Boex, J. (1997). Fiscal capacity: an overview of concepts and measurements issues and their applicability in the Russian Federation, GSU.

\section{Note}

Note 1. A current currency in Republic of Macedonia (denar, den., MKD).

\section{Copyrights}

Copyright for this article is retained by the author(s), with first publication rights granted to the journal.

This is an open-access article distributed under the terms and conditions of the Creative Commons Attribution license (http://creativecommons.org/licenses/by/3.0/). 